\title{
Classification of a Child's Special Needs in the Context of a Systematic Approach
}

\section{Класифікація особливих потре6 дитини в контексті системного підходу}

Iryna Kuchmanych Ph.D. in Psychology, Assistant Professor

\author{
Ірина Кучманич \\ кандидат психологічних \\ наук, доцент
}

Liudmyla Opanasenko

Lecturer of the Department of Psychology
E-mail:irina.kychmanich@gmail.com orsid.org/0000-0002-6954-6082
Researcher ID: S-4412-2018

Mykolaiv V.O.Sukhomlynskyi National University, Ukraine 24, Nikolska str., Mykolaiv, Mykolaiv region, 54030

\author{
Людмила Опанасенко \\ викладач кафедри психології
}

E-mail: luidmilkaop@ukr.net orsid.org/0000-0001-6641-4634

Researcher ID: U-3102-2018

$$
\begin{aligned}
& \text { м. Миколаїв, Миколаївська } \\
& \text { обл., } 54030
\end{aligned}
$$

Миколаївський національний університет ілені В.О. Сухоллинського, Украӥна вул. Нікольська, 24,

Original manuscript received June 04, 2018 Revised manuscript accepted November 07, 2018

\section{ABSTRACT}

The social development of the state is connected with the solution of a number of acute social problems, among which the socialization of children with special needs is extremely important. The special needs of the child are deter- 
mined by social, physical and emotional vulnerability and, as a consequence, the need for special attention and services to enable their potential development. Despite the large number of works devoted to the study of various aspects of the life of children with special needs, it should be stated that in modern scientific researches there is neither systematic classification of the special needs of children, nor their essence disclosure.

In the article it is proposed the classification of special needs in the context of the system approach by studying the interaction of the child (as a component of the system) with other systems of different levels and a brief description of them.

It is found that at the level of interaction "child - family» (microsystem) it is possible to distinguish the following needs of the child, such as: the need for the presence of one another; need for adoption by parents and siblings; the need for constant emotional support. The needs of the level of interaction "child - the closest environment" (mesosystem) include: the need for adoption; need for self-affirmation; need for qualified medical assistance; need for psychological support. A group of needs actualized by the interaction of "child - out-of-family social institutions» (exosystem) consists in: the need for health care; need for social protection; need for education; material needs. The needs of the level of interaction "child-society" (macrosystem) include: the need for a tolerant attitude of society; need for economic and political support.

It is established that the specific needs of children are determined by the lack of personal resources for optimal physical and social and psychological development. The proposed classification will help to determine the means of social support for the identified social category at different levels of interaction with the social environment.

Key words: need, special needs, children with special needs, system approach, microsystem, mesosystem, exosystem, macrosystem.

\section{Вступ}

Провідним завданням соціального розвитку сучасної України є забезпечення захисту, рівних прав і можливостей для усіх її громадян. На шляху до його вирішення постає низка гострих проблем, серед яких украй актуальною є соціальна адаптація й інтеграція дітей з особливими потребами. Зазначена категорія дітей є однією з найуразливіших, потребує якісної соціально-психологічної допомоги і підтримки на всіх рівнях функціонування. 
Поняття «особливі потреби» на сучасному етапі розвитку суспільства є досить уживаним. Воно поступово витісняє із загального і професійного використання слова "аномалія», «інвалідність», «вади розвитку», «дефект» тощо. Поява нового терміна зумовлена тим, що відбувається еволюція підходів (відповідно, й термінології) в напрямку акцентування уваги на ефективній соціалізації осіб різних категорій і реалізації ними основоположних прав у різних сферах життя. Саме тому використовуються такі терміни, де на першому місці стоїть особистість, а її стани (особливості) - на другому.

Термін «особливі потреби» застосовується стосовно осіб, чия соціальна, фізична або емоційна особливість потребує спеціальної уваги та послуг, задля того, щоб уможливити розвиток їх потенціалу (в тому числі й освітнього) (Шевців, 2016). Світові та вітчизняні вчені активно досліджують сутність особливих потреб, визначають особливості соціальної інтеграції дітей з особливими потребами. Так, особливі потреби стали предметом наукових розвідок Л. Дивнич (Дивнич, 2016), D.O. Fareo (Fareo, 2015), E.D. Ozoji (Ozoji, 2006), J. Wilson (Wilson, 2012); специфiку соціально-психологічного супроводу дітей із порушеннями розвитку вивчали О. Василенко (Василенко, 2010), О. Волошин (Волошин, 2015), С. Іноземцева (Іноземцева, 2009), І. Макаренко (Макаренко, 2010), Т. Соловйова (Соловйова, 2009) та ін.; особливості впровадження інклюзивної освіти з урахуванням особливих потреб дитини досліджували А. Колупаєва (Колупаєва, 2017), G. Lindsay (Lindsay, 2003), D. Mitchell (2013), В. Засенко (Засенко, 2016) та ін. Водночас поза увагою науковців залишаються питання класифікації та диференціації цих потреб; порівняльний аналіз потреб дітей, які мають особливості розвитку, з потребами більшості; визначення генези виникнення певних особливих потреб у процесі соціалізації.

Мета статті - визначити та схарактеризувати типи особливих потреб дитини в контексті їі взаємодії з соціальними інституціями різних систем. 


\section{Завдання статті}

1) Охарактеризувати поняття «особливі потреби дитини» ;

2) виокремити провідні соціальні інституції різних рівнів і висвітлити особливості розвитку дитини в системі соціальних зв'язків;

3) визначити типи та розкрити сутність особливих потреб дитини у розрізі системного підходу.

\section{Методи дослідження}

У дослідженні використано комплекс теоретичних методів. Зокрема, аналіз сучасних досліджень проблеми розвитку дитини у процесі взаємодії з системою соціальних інституцій; узагальнення дослідних даних щодо феномену особливих потреб у дітей; систематизація уявлень щодо існуючих соціальних інституцій у межах мікросистеми, мезосистеми, екзосистеми, макросистеми; класифікація особливих потреб дитини у контексті взаємодії з системами різних рівнів.

\section{Результати та дискусії}

Психологи визначають поняття «потреба» як джерело активності особистості. У загальному розумінні потреба - це стан індивіда, зумовлений нуждою та необхідний для його існування й розвитку. С.Д. Максименко зазначає, що потреба є похідною від нужди. Нужда є вихідною інтенцією, що має подвійне призначення: з одного боку, є чисто природним, біологічним поштовхом, який зумовлює розвиток механізмів входження у світ. 3 іншого боку, соціальна складова нужди штовхає людину до саморозвитку зсередини, із себе самої. Нужда - це «двигун», який працює все життя: від зачаття до смерті. На грунті нужди розвиваються предметні потреби - біологічні, фізіологічні, соціальні, пізнавальні тощо (Максименко, 2014).

Загальноприйнятою у психологічній науці та практиці є класифікація потреб А. Маслоу. В ієрархічній моделі 
вченого зазначається, що задоволення психологічних потреб можливе лише після задоволення базових фізичних потреб. S. Epstein i K. Grawe розробили концепцію базових потреб на основі емпіричних досліджень, де брали участь винятково дорослі люди (Grawe, 2006). Утім, у сучасних наукових розвідках підкреслюється, що варто розрізняти потреби дітей і потреби дорослих. Tак, Michael BorgLaufs виокремлює базові потреби дітей (на основі теорії K. Grawe). Зокрема, вчений визначає чотири основні потреби, розуміння яких допомагає краще зрозуміти проблеми дітей: орієнтація / контроль; захист самооцінки; отримання задоволення / уникнення дистресу; прив'язаність (Borg-Laufs, 2013).

Окрім зазначених базових потреб, характерних для більшості, у деяких дітей існують специфічні потреби відповідно до особливостей їх розвитку. Особливі потреби виникають у дітей, які мають відмінні від середніх показники розвитку (надзвичайно низькі або високі) та потребують спеціальних підходів (методів, технологій, програм тощо) для розвитку їх потенціалу, соціальної адаптації й інтеграціï. B. Ali зазначає, що діти з особливими потребами потребують додаткової уваги практично в усіх сферах життя (Ali, 2003).

Варто наголосити, що особливі потреби можна розглядати у двох взаємопов'язаних площинах: особливі потреби дитини з огляду на специфіку їі індивідуального розвитку; особливі потреби дитини, що виникають у системі взаємодії з соціальними інституціями різних рівнів. Щодо першого аспекту, то мова йде про особливості розвитку тілесної, емоційної, когнітивної та духовної сфер дитини. У цьому контексті особливі потреби можна виокремити шляхом спеціального діагностичного інструментарію (методик дослідження когнітивних процесів, емоційно-вольової сфери, інтелекту тощо). Наприклад, унаслідок психодіагностики встановлено, що в дитини є затримка психічного 
розвитку. Отже, у неї існує низка особливих потреб (порівняно з іншими дітьми цього віку): потреба в розвитку дрібної моторики, потреба в розвитку когнітивних процесів, потреба в розвитку емоційної сфери тощо. Класифікація потреб у цьому контексті базується на результатах психодіагностичного обстеження дітей.

Другий аспект пов'язаний із процесом взаємодії дитини з особливими потребами з різними соціальними інституціями. М. Селігман і Р. Дарлінг зазначають: «Особливі діти живуть не в ізоляції» (Селігман, 2009: 29). Дитина є членом сімейної системи, яка є найближчою та найбільш значущою для неї. Водночас сімейна система є складовою ширшого соціального контексту і постійно взаємодіє з різними соціальними інституціями. Так, U. Bronfenbrenner наприкінці XX століття розробив соціально-екологічну модель, де описав взаємодію сім’ї з низкою різних соціальних структур. Ключова думка теорії соціальної екології: вивчати поведінку особистості можливо лише з урахуванням умов їі існування. Тобто, на сім'ю впливає сукупність різних зовнішніх чинників, що позначаються на функціонуванні сімейної системи й кожного її члена (Garbarino, 2017). Саме тому неможливо вивчати розвиток дитини поза межами соціального оточення.

Класифікація особливих потреб у контексті системного підходу передбачає вивчення взаємодії дитини (як складної системи) з іншими системами різних рівнів. Згідно 3 U. Bronfenbrenner, у структурі соціуму можна виокремити чотири підсистеми: мікросистему, мезосистему, екосистему, макросистему (Garbarino, 2017). D. Mitchell уперше застосував концепцію соціальної екології до вивчення сімей, які мають дітей із порушеннями розвитку (Селігман, 2009). Дослідження вченого дали підстави констатувати, що сім'я з особливою дитиною є надзвичайно чутливою до впливу всіх підсистем. Відтак, розвиток дитини багато в чому залежить від специфіки її взаємодії з різними соці- 
альними інституціями. Саме така взаємодія актуалізує ті потреби дитини, що «найбільше відповідають їі укоріненій нужді» (Максименко, 2014: 12).

Виокремлення базових груп особливих потреб дитини в контексті системного підходу передбачає з'ясування особливостей взаємодії у системах: «дитина - сім'я», «дитина - найближче оточення», «дитина - позасімейні соціальні інституції, «дитина - соціум» (рис. 1).

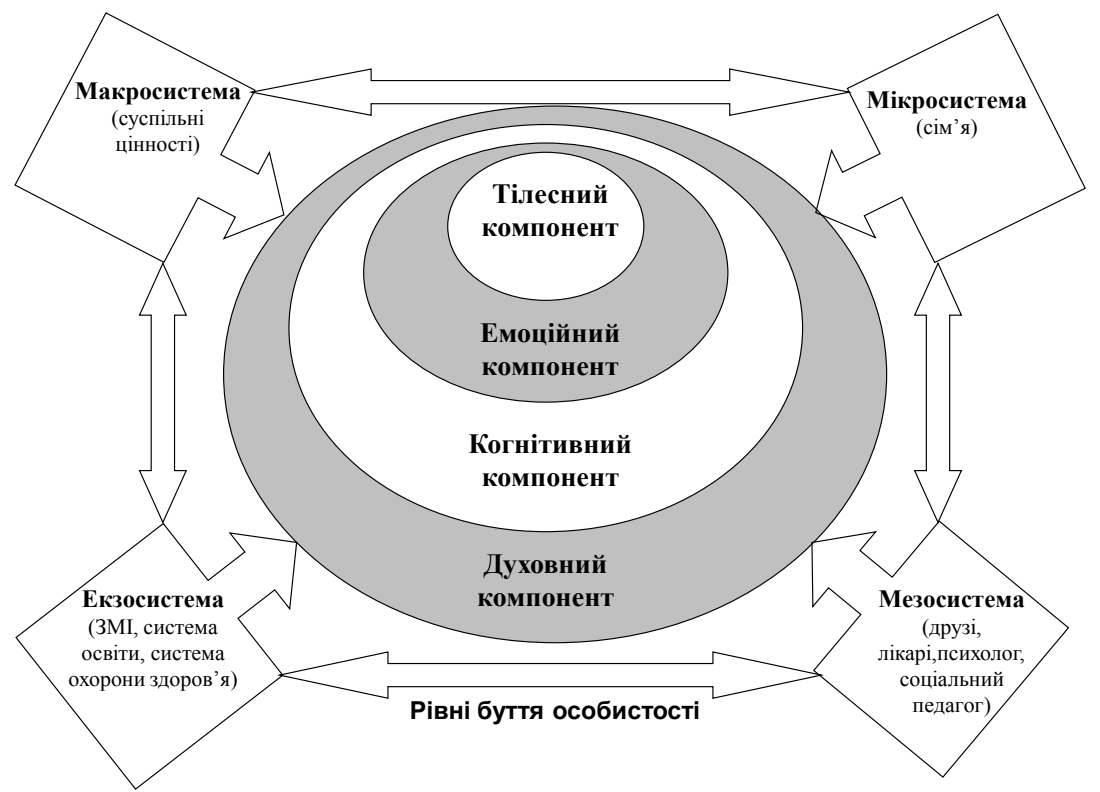

Puc. 1. Функціонування дитини з особливими потребами у соціальних системах

Взаємодія в систелі “дитина - сім'я" (рівень мікросистели) зумовлює виникнення низки особливих потреб y дитини. Народження дитини з особливими потребами є своєрідним викликом для сім’ї й потребує значних сімейних ресурсів. Утім, саме батьки мають бути спроможними витримати безсилля дітей і контейнувати їх негативні емоції (Fareo, 2015). 
1. Потреба в присутності іншого. Діти, які мають особливості розвитку та вади здоров'я ще з народження, здебільшого не можуть реалізовувати частину базових потреб самостійно. Відповідно така категорія дітей потребує постійної присутності іншого у своєму житті. Часто таким «Іншим» стають батьки. Варто зазначити, що діти 3 особливими потребами у цьому контексті відрізняються від решти дітей, які у процесі онтогенезу дорослішають і з кожним роком усе менше потребують участі дорослих у своєму житті. Діти з певними порушеннями суттєво обмежені у вияві власної самостійності, через що батьки знаходяться постійно поруч із ними з метою задоволення їх базових потреб. У випадку, якщо дитина не отримує такої допомоги в сім’ї, це, по-перше, загрожує її життю. 3 іншого боку, посилює відчуття власної неповноцінності та провокує хронічне переживання небезпеки, а, відтак, і недовіри до світу (за Е. Еріксоном). Базове переживання недовіри до світу, яке формується в перший рік життя дитини, значно утруднює й так складний для особливої дитини процес їі соціалізації та інтеграції в суспільство.

Якщо дитина захворіла чи отримала травму на певному етапі свого життя (тобто не з народження), то підтримка з боку батьків є важливою умовою ефективного переживання цієї психотравмуючої ситуації. Батьки, які здійснюють догляд за своєї дитиною та допомагають їй реалізувати свої потреби, з одного боку, допомагають дитині виживати фізично. 3 іншого боку, це сприяє усвідомленню дитиною того, що вона - повноцінний член суспільства.

2. Потреба у прийнятті батькали та сиблінгали. У загальному контексті «прийняття» це складний процес, що грунтується на такому сприйнятті реальності, яке не викривлено стереотипами, негативними настановами, страхами, ілюзіями, очікуваннями тощо. В основі такого сприйняття немає оцінок. Прийняття - це не пасивне пристосування, а активний процес усвідомлення й адекватного ставлення особистості до власних обмежень (тобто до того, 
що людина не може змінити); визнання багатоваріантності й «інакшості» форм існування. Відомо, що уявлення та ставлення щодо власного «Я» в дитини обумовлені, здебільшого, саме ставленням до неї членів сім’ї. Діти, які мають особливості розвитку, на певному етапі свого життя усвідомлюють свою відмінність від решти однолітків. Якщо батьки приймають дитину, то дитина вчиться усвідомлювати та визнавати свої позитивні якості, негативні сторони, обмеження тощо.

Особлива роль у процесі прийняття дитини з особливими потребами членами сім'̈і належить братам і сестрам (сиблінгам). Брати / сестри - це підсистема рівних і рідних водночас. Учені зазначають, що взаємини між сиблінгами найміцніші з усіх видів сімейних стосунків. Тривалість цих стосунків дає змогу двом індивідам здійснювати значущий вплив один на одного, який у більшості випадків поширюється на все життя (Селігман, 2009). Відповідно, брати й сестри, з одного боку, є значущими рідними для дитини, а з іншого боку - вони є для дитини друзями, однолітками, радниками тощо. 3 їхньою допомогою дитина з особливими потребами активніше пізнає світ однолітків. Прийняття з боку братів і сестер дає змогу особливій дитині відчути себе повноцінним членом дитячого колективу.

3. Потреба в постійній елоційний підтрилиі. Сутність емоційної підтримки полягає в тому, щоб розуміти емоції іншої людини, вміти їх витримувати та поділяти. Емоційна підтримка також виявляється в прийнятті ди-

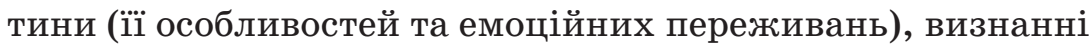
її людської цінності й значущості. Якщо батьки навчаться розуміти емоційні переживання дитини, витримувати та контейнувати їх (дозволяти дитині переживати будь-які негативні й позитивні емоції та почуття), то в такому випадку дитина відчуває цю емоційну підтримку. Дитина 3 особливими потребами найбільше потребує емоційної підтримки, особливо в межах сім’ї. У результаті такої підтримки в дитини з'являється довіра до себе, інших людей i 
світу загалом. Урешті-решт, це сприяє ефективнішій адаптації дитини до взаємодії з іншими соціальними інституціями.

Взаємодія в системі «дитина - найближче оточення" (рівень мезосистели). Мезосистема - це найближче оточення дитини поза межами нуклеарної сім’ї (родичі, друзі, вихователі / вчителі, медичні працівники, психологи тощо). Варто наголосити, що діти з порушеннями розвитку тривалий час (інколи все життя) активно взаємодіють із різними фахівцями. Відтак, вони стають найближчим позасімейним оточенням дитини. Фахівці, які співпрацюють із сім'ями з особливими дітьми, мають ураховувати особливості взаємин між дітьми та їхніми батьками для того, щоб адаптувати послуги, що вони надають, до потреб дитини і сім'ї загалом (Ritzema \& Sladeczek, 2011).

1. Потреба в прийнятті. На цьому рівні мова йде про прийняття з боку найближчого соціального оточення (поза межами нуклеарної сім’ї). У це коло можна віднести знайомих і друзів сім’ї; друзів дитини; родичів; сімейного лікаря; психолога, соціального педагога; сусідів; учителя, тренера.

Прийняття дитини з боку цих людей передбачає: здатність фахівців (сімейного лікаря; психолога, соціального педагога; вчителя тощо) виконувати свою роботу не формально, а встановлювати емоційний контакт із дитиною (бути з нею чесними, доброзичливими, чуйними); готовність родичів (сусідів) надати дитині та сім'ї фізичну і посильну психологічну підтримку; вміння співчувати, бути відкритими; ставлення до дітей як до повноцінних членів суспільства, без зайвої та нав'язливої уваги; активне залучення дитини з особливими потребами до суспільного життя (запрошення на дні народження, участь у суспільних заходах тощо).

Для дитини з особливими потребами взаємодія з іншими людьми поза межами нуклеарної сім’ї- це, перш за все, взаємодія з представниками різних соціальних інституцій. 
Якщо оточення приймає особливості дитини, ставиться до неї доброзичливо, але без зайвої концентрації уваги, то це дає змогу дитині повірити в себе. Зрештою, це спонукає дитину до розвитку максимально можливого для неї рівня соціалізації.

2. Потреба в салоствердженні. У загальному контексті потреба в самоствердженні передбачає прагнення дитини до усвідомлення себе та свого місця в системі людських стосунків. Ця потреба актуалізується в дошкільному віці, активно розгортається у підлітковий період і не втрачає своєї значущості впродовж усього життя людини. Вона визначає психологічну залежність від найближчого оточення, проявляється як у глибинній ідентифікації з іншими, так і в різкому відчуженні від них (зважаючи на деяку «інакшість»).

Прагнення до самоствердження стимулює певні типи поведінки, серед яких можна виокремити як конструктивні, так і деструктивні варіанти. Поведінковий репертуар дитини на шляху до самоствердження зумовлений різними чинниками, провідними серед яких є рівень самооцінки та рівень домагань. За умови низьких показників їх розвитку, потреба у самоствердженні не є надто вираженою. Через потужну фіксацію на власних недоліках дитина поводиться досить пасивно, прагне до виконання найпростіших або добре знайомих завдань. При переоцінці своїх можливостей - схильна братися за справу, яку часто не здатна виконати. Така ситуація важко переживається дитиною, призводить до розчарувань, відчуття перевтоми, безвиході та зневіри у власній спроможності.

Особливість потреби в самоствердженні полягає в тому, що дитині надзвичайно важко (іноді неможливо без допомоги й підтримки близького оточення) повірити в себе, розпізнати свої бажання, зосередити увагу на особистих прагненнях, розвивати власні ефективні поведінкові стратегії щодо досягнення бажаного результату. Потреба в са- 
моствердженні є однією з найбільш значущих для дитини з особливими потребами, оскільки виступає стимулом її соціального розвитку і саморозвитку.

3. Потреба в кваліфікованій медичній дополозі. Більшість дітей з особливими потребами перебувають під постійним наглядом медичних фахівців. Їх фізичний стан (основний діагноз і супроводжуючі його ускладнення) зумовлює необхідність у наданні систематичної медичної допомоги. Вони гостро потребують якісного медичного огляду / тестування, ефективного лікування, а також заходів, спрямованих на визначення розподілу фізичних і психологічних навантажень; формування стереотипів поведінки, що відповідають фізичним, соматичним і психічним можливостям дитини; сприяння розвитку позитивно-адекватного ставлення до себе і навколишнього середовища. Водночас медична допомога повинна поєднуватися з емоційною підтримкою дитини з боку лікарів та інших медичних працівників. Працюючи за певним загальним алгоритмом, медикам слід ураховувати специфічність потреб дитини та навчити її адекватному ставленню до своїх індивідуальних особливостей.

4. Потреба в психологічнолу супроводі. Діти з особливими потребами у процесі дорослішання та включення в соціальні стосунки з іншими людьми відчувають брак особистих соціально-психологічних ресурсів для повноцінного функціонування у межах мезосистеми. Здебільшого, це обумовлено недостатнім розвитком вищих психічних функцій, емоційною неврівноваженістю, патологічністю рис характеру, несформованістю важливих особистісних якостей і соціально-психологічних умінь. Зазначені вище особливості досить важко корегуються, проте піддаються змінам за умов цілеспрямованого та тривалого психологічного супроводу.

Вивчення характеру потреб у психологічному супроводі (підбір діагностичного інструментарію, психодіагности- 
ка) та надання психологічної допомоги, пов'язаної з ними (консультування, психологічна підтримка, психокорекція) - складне завдання, що реалізується у межах діяльності практичного психолога. Проте психологічний супровід дітей з особливими потребами не може відноситися суто до сфери професійних обов'язків одного фахівця, адже він знаходиться на перетині функцій усіх спеціалістів, які безпосередньо взаємодіють з цією соціальною категорією.

Взаєлодія в систелі "дитина - соиіальні інституиї̈» (рівень екзосистели). Соціальні інституції функціонують у вигляді соціальних практик, що розгортаються у структурі суспільства. Рівень екзосистеми утворюють: системи освіти, охорони здоров'я, соціального захисту, засоби масової інформації тощо. Діти з особливими потребами перебувають у певній залежності від діяльності соціальних інституцій, оскільки останні задовольняють їх основні потреби в охороні здоров'я та соціальному захисті, освітні та матеріально-побутові потреби.

1. Потреба в охороні здоров'я. Охорона здоров'я - це забезпечення доступного медичного обслуговування на державному рівні. Зважаючи на ускладнений психосоматичний стан переважної більшості дітей з особливими потребами, необхідність в охороні їхнього здоров'я з боку соціальних інституцій завжди досить гостро виражена. Окрім систематичної медичної діагностики та лікувально-оздоровчої роботи, такі діти потребують: постійного контролю фізичного розвитку й імунологічних особливостей; профілактики захворювань, до яких є схильність; періодичного диспансерного спостереження; медичної реабілітації - відновлення втрачених функцій, активізації компенсаторних можливостей організму; санаторно-курортного лікування й оздоровлення; медичного патронажу (за важких форм інвалідності виникає потреба у постійному сторонньому догляді за дитиною); підтримання нормального рівня життєдіяльності організму; формування мотивації до здорового способу життя тощо. 
2. Потреба в соиіальнолу захисті. Діти з особливими потребами - соціально вразлива категорія населення, яка потребує соціального захисту з боку держави. Шляхом упровадження системи пільг і соціальних гарантій розбудовується суспільне середовище рівних можливостей та забезпечується безперешкодний доступ до об'єктів соціальної інфраструктури. Потреба в соціальному захисті визначає коло організаційно-правових й економічних питань щодо безоплатного матеріального, соціально-побутового і медичного забезпечення. Вона не віддзеркалює безпосередніх інтересів кожного індивіда, проте значно знижує соціальну напругу, пов'язану з обмеженістю можливостей дітей з особливими потребами. На сучасному етапі потреба в соціальному захисті реалізується шляхом надання соціальної допомоги, упровадження реабілітаційних програм і заходів щодо активізації життєдіяльності дітей з особливими потребами.

3. Потреба в отриланні освіти. У процесі набуття соціального досвіду поступово формується потреба в цілеспрямованій пізнавальній діяльності, освіті. Навчання дітей з особливими потребами в закладах освіти забезпечується шляхом упровадження інклюзії. Інклюзивне навчання передбачає створення освітнього середовища, яке б відповідало потребам і можливостям кожної дитини, незалежно від особливостей її психофізичного розвитку. Інклюзивні заклади спрямовані на спектр необхідних послуг відповідно до різних освітніх потреб дітей. Особливі освітні потреби - це потреби в умовах, необхідних для оптимальної реалізації можливостей дітей.

Серед потреб цього виду виокремлюють: когнітивні потреби, пов'язані з утрудненням миследіяльних операцій, можливостями запам'ятовування і збереження інформації, обсягом знань і уявлень; енергетичні потреби, зумовлені заниженим рівнем розумової активності та працездатності переважної більшості дітей цієї соціальної категорії; емоційно-вольові потреби, детерміновані особливостями 
пізнавальної мотивації дітей (переважанням зовнішніх мотивів у навчальній діяльності, ситуативністю мотивації, необхідністю постійної підтримки навчального інтересу і стимулювання навчання).

Важливо відзначити той факт, що освітні потреби дітей не є постійними, вони виявляються залежно від типу порушення психофізичного розвитку.

4. Матеріально-побутові потреби. У сім'ї, де зростає дитина з особливими потребами, значно зростає кількість матеріально-побутових проблем. Серед розмаїття матеріально-побутових труднощів найпоширенішими є такі: непристосованість житла до фізіологічних особливостей дитини або відсутність спеціальних пристосувань для їi оптимального функціонування (ортопедичного взуття, слухового апарата, інвалідного візка тощо); недостатність коштів для лікування й оплати необхідних медичних послуг (хірургічного втручання, масажів, реабілітаційних процедур тощо); відсутність можливості для збалансованого та повноцінного харчування дитини; неспроможність забезпечення нормального відпочинку.

Сьогодні в Україні існують різноманітні соціальні програми, спрямовані на вирішення гострих матеріально-побутових потреб дітей з особливими потребами та їх сімей, проте на їх результативність дуже негативно впливає загальна економічна ситуація в країні та збільшення кількості осіб цієї категорії.

Взаєлодія в систелі «дитина - суспільство» (рівень лакросистели). Рівень макросистеми характеризується сукупністю норм, законів, соціальних цінностей, традицій і взірців поведінки, що визначають особливості функціонування суспільства. Водночас цінності суспільства опосередковано впливають на становлення особистості дитини (особистісна підсистема є складовою суспільства як системи) та віддзеркалюють особливості піклування суспільства про неї. 


\section{1. Потреба в толерантному ставленні суспіль-} ства. Діти з особливими потребами досить добре знайомі з ситуаціями дискримінації та соціальної ізоляції. Брак тактовності, брутальність, відсутність розуміння та прийняття з боку оточуючих спричинюють ускладнення процесу соціалізації й такі діти здебільшого залишаються практично поза межами реальної інтеграції. Відповідно, потреба в толерантному ставленні є однією з основних, виступає фундаментом для встановлення діалогу та взаєморозуміння між дитиною й соціумом. Хоча толерантність не є універсальною моральною цінністю, проте вона повинна бути закладена в основу норм загальної суспільної поведінки.

2. Потреба в економічній і політичній підтримиі. Забезпечення фінансової та юридичної підтримки - необхідна умова для реалізації особистісного потенціалу дитини з особливими потребами. Повноцінне функціонування на рівні макросистеми неможливе без запровадження відповідних нормативно-правових документів і соціальних програм. На жаль, значна частина положень соціальноекономічної політики щодо дітей з особливими потребами застаріла й не відповідає вимогам сьогодення. Крім того, деякі з них не узгоджуються із загальновизнаними високогуманними міжнародними нормами і стандартами. Правове поле хоча і містить багато позитивних кроків на шляху вирішення численних проблем, утім $є$ переважно декларативним, не підкріпленим матеріальними ресурсами та механізмами управлінського впровадження.

Запропонована класифікація особливих потреб дитини в контексті системного підходу схематично представлена на рис. 2 .

Варто наголосити, що системи різних рівнів впливають на особистість безпосередньо (мікросистема та мезосистема) й опосередковано (екзосистема та макросистема). Відповідно й потреби дитини видозмінюються залежно від соціального контексту й оточення. 


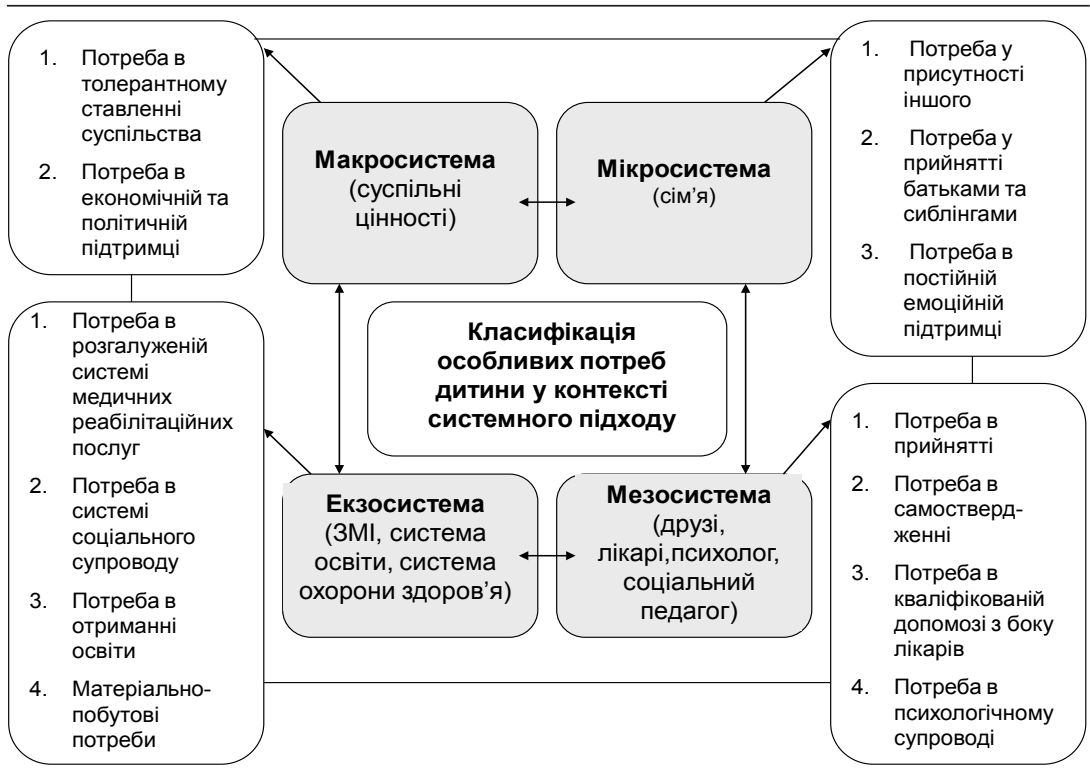

\section{Puc. 2. Класифікація особливих потреб дитини \\ в контексті системного підходу}

\section{Висновки}

Особливі потреби виникають у дітей, які мають певні відмінності розвитку (порівняно з рештою) та потребують упровадження спеціальних підходів для оптимальної соціалізації. У контексті системного підходу особливі потреби актуалізуються при взаємодії дитини із системами різних рівнів: мікросистемою, мезосистемою, екзсосистемою та макросистемою. Виникнення потреб пов'язано з наявністю нужди в дитини, браком особистих ресурсів для її реалізації та відсутністю засобів соціальної підтримки водночас. Запропонована класифікація особливих потреб дитини є своєрідною спробою окреслення ключових проблем, вирішення яких сприяє їх оптимальному розвитку. Перспективи подальших досліджень зосереджені навколо питань порівняльного аналізу потреб осіб, які мають особливості розвитку, з потребами більшості дітей. 


\section{Література}

Василенко О.М. Соціально-педагогічні умови адаптації молодших школярів з особливими потребами до навчання в загальноосвітній школі : автореф. дис. ... канд. пед. наук : 13.00.05. Луганськ, 2010. 20 c.

Волошин О. Робота з дітьми з особливими освітніми потребами. Психологічна готовність педагогів. Психолог - Psychologist. 2015. № $7 / 8$. С. 74-76.

Дивнич Л. Соціалізація дитини з особливими потребами. Соціальний пеdazoz - Social teacher. 2016. № 2. C. 34-37.

Засенко В.В. Освіта "особливих» дітей: стан і перспективи розвитку. Педагогіка і психологія - Pedagogics and psychology. 2016. № 4. C. 19-23.

Іноземцева С.В. Організація соціально-педагогічної роботи з підлітками з особливими потребами в середніх навчальних закладах України (друга половина ХХ століття) : автореф. дис. ... канд. пед. наук : 13.00.01. Харків, 2009. 21 с.

Колупаєва А.А. Сучасна інклюзивна парадигма в освіті дітей з особливими потребами. Педагогіка i nсихологія - Pedagogics and psychology. 2017. № 1. С. 57-63.

Кучманич I.M. До питання ґенези особливих освітніх потреб дитини в умовах сім’ї. Трансфорлаційні зліни особистості студентської лолоді засобали професійної освіти : Матеріали Всеукраїнської науково-практичної конференції з міжнародною участю (Миколаїв, 17 квітня 2018 р.) / Миколаївський національний університет імені В.О. Сухомлинського. Миколаїв : ІЛІОН, 2018. С. 23-25.

Кучманич I.M., Опанасенко Л.А. Феномен соціальної обумовленості освітніх потреб: психологічний аспект проблеми. Особистість у кризових умовах та критичних ситуаціях життя : Матеріали IV Міжнародної науково-практичної конференції (Суми, 22-23 лютого 2018 р.) / Сумський державний педагогічний університет імені А.С. Макаренка. Суми : Вид-во СумДПУ імені А.С. Макаренка, 2018. С. 366-368.

Макаренко I.В. Соціально-педагогічні засади роботи з батьками дітей з особливими потребами : автореф. дис. ... канд. пед. наук : 13.00.05. Луганськ, 2009. 20 с.

Максименко С.Д. Теорія психології нужди (життєвої енергіï). Проблеми сучасної психологї - Problems of modern psychology. Вип. 25. Кам'янець-Подільський : Аксіома, 2014. С. 7-23.

Селигман М., Дарлинг Р. Обычные семьи, особые дети : [пер. с англ.]. Изд. 2-е. М. : Теревинф, 2009. 368 с.

Соловйова Т.Г. Соціально-педагогічна підтримка батьків дітей раннього віку з особливими потребами : автореф. дис. ... канд. пед. наук : 13.00.05. Київ, 2009. 22 с. 
Чайковський М.Є. Теорія і практика соціально-педагогічної роботи 3 молоддю з особливими потребами в умовах інклюзивного освітнього простору : дис. ... д-ра пед. наук : 13.00.05. Старобільськ, 2016. 488 c.

Шевців 3.М. Теоретичні основи інклюзивної педагогіки. Оновлення злісту, форл та методів навчання і виховання в закладах освіти - Updating content, forms and methods of education in educational institutions. Наукові записки Рівненського державного гуманітарного університету. Вип. 13 (1). Рівне : РДГУ, 2016. С. 152-155.

Ali, B.A. (2003). The relevance of counselling in the provision of quality education for the exceptional children in Nigeria. Gobarau Journal of Education, 4 (2), 111-118.

Borg-Laufs, M. (2013). Basic Psychological Needs in Childhood and Adolescence. Journal of Education and Research, 3 (1), 41-51.

Fareo, D.O. (2015). Counselling Intervention and Support Programmes for Families of Children with Special Educational Needs. Journal of Education and Practice, 6 (10), 103-109.

Garbarino, J. (2017). Children and Families in the Social Environment : Modern Application of Social Work. New York : Routledge. 390 p.

Grawe, K. (2006). Neuropsychotherapy : How the Neurosciences Inform Effective Psychotherapy. London : Erlbaum. 502 p.

Lindsay, G. (2003). Inclusive education: a critical perspective. British Journal of Educational Psychology, 30 (1), 3-12.

Mitchell, D. (2013). Proposed values, knowledge and skill sets for educators working in inclusive settings with learners with diverse educational needs. Baltic Journal of Special Education, 2 (29), 145-157.

Ozoji, E.D. (2005). Selected issues in special education. Jos : Deka publications.

Ritzema, A., \& Sladeczek, I. (2011). Stress in Parents of Children with Developmental Disabilities over Time. Journal on Developmental Disabilities, $17,18-31$.

Wilson, J. (2002). Defining «special needs». European Journal of Special Needs Education, 17, 61-66.

\section{References}

Vasylenko, O.M. (2010). Sotsialno-pedahohichni umovy adaptatsii molodshykh shkoliariv $z$ osoblyvymy potrebamy do navchannia $v$ zahalnoosvitnii shkoli [Social and pedagogical conditions of adaptation of junior pupils with special needs to study at a comprehensive school]. Extended abstract of candidate's thesis. Luhansk [in Ukrainian].

Voloshyn, O. (2015). Robota z ditmi z osoblyvymy osvitnimy potrebamy. Psykholohichna gotovnist pedahohiv [Work with children having special educational needs. Psychological readiness of teachers]. Psykholoh-Psychologist, 7/8, 74-76 [in Ukrainian]. 
Dyvnych, L. (2016). Sotsializatsiia dytyny z osoblyvymy potrebamy [Socialization of a child with special needs]. Sotsialnyi pedahoh-Social teacher, 2, 34-37 [in Ukrainian].

Zasenko, V.V. (2016). Osvita «osoblyvykh» ditei : stan i perspektyvy rozvytku [Education of «special» children : the state and prospects of development]. Pedahohika i psykholohiia - Pedagogics and psychology, 4, 19-23 [in Ukrainian].

Inozemtseva, S.V. (2009). Organizatsiia sotsialno-pedahohichnoi roboty $z$ pidlitkamy z osoblyvymy potrebamy $v$ serednikh navchalnykh zakladakh Ukrainy (druha polovyna XX stolittia) [Organization of socialpedagogical work with adolescents having special needs in secondary schools of Ukraine ( second half of the twentieth century)]. Extended abstract of candidate's thesis. Harkiv [in Ukrainian].

Kolupaieva, A.A. (2017). Suchasna inkliuzyvna paradyhma v osviti ditei z osoblyvymy potrebamy [Modern inclusive paradigm in the education of children with special needs]. Pedahohika i psykholohiia - Pedagogics and psychology, 1.57-63 [in Ukrainian].

Kuchmanych, I.M. (2018). Do pytannia genezy osoblyvykh osvitnikh potreb dytyny $\mathrm{v}$ umovakh simi [On the issue of the genesis of special educational needs of the child in the conditions of the family]. Transformatsiini zminy osobystosti studentskoi molodi zasobamy profesiinoi osvity [Transformational changes in the personality of student youth through means of professional education ] : Materialy Vseukrainskoi naukovo-praktychnoi konferentsii z mizhnarodnoiu uchastiu. Mykolaivskyi natsionalnyi universytet imeni V.O. Sukhomlynskoho (pp. 23-25). Mykolaiv : ILION [in Ukrainian].

Kuchmanych, I.M., \& Opanasenko, L.A. (2018). Fenomen sotsialnoi obumovlenosti osvitnikh potreb: psykholohichnyi aspekt problemy [The phenomenon of social conditionality of educational needs: the psychological aspect of the problem]. Osobystist u kryzovykh umovakh ta krytychnykh sytuatsiiakh zhyttia [Personality in crisis conditions and critical situations of life ] : Materialy IV Mizhnarodnoi naukovo-praktychnoi konferentsii. Sumskyi derzhavnyi pedahohichnyi universytet imeni A.S. Makarenka (pp. 366-368). Sumy : Vyd-vo SumDPU imeni A.S. Makarenka [in Ukrainian].

Makarenko, I.V. (2009). Sotsialno-pedahohichni zasady roboty z batkamy ditei z osoblyvymy potrebamy [Social and pedagogical principles of work with parents of children having special needs]. Extended abstract of candidate's thesis. Luhansk [in Ukrainian].

Maksymenko, S.D. (2014). Teoriia psykholohii nuzhdy (zhyttievoi energii) [Theory of psychology of need (life energy)]. Problemy suchasnoi psykholohii - Problems of modern psychology, 25, 7-23. KamianetsPodilskyi : Aksioma [in Ukrainian]. 
Seligman, M., \& Darling, R. (2009). Obychnye semji, osobye deti [Ordinary families, special children ]: Izd. 2-e. Moskva : Terevinf [in Russian].

Soloviova, T.H. (2009). Sotsialno-pedahohichna pidtrymka batkiv ditei rannogo viku z osoblyvymy potrebamy [Social and pedagogical support of parents of children of early age with special needs ]. Extended abstract of candidate's thesis. Kyiv [in Ukrainian].

Chaikovskyi, M.E. (2016). Teoriia i praktyka sotsialno-pedahohichnoi roboty $z$ moloddiu z osoblyvymy potrebamy $v$ umovakh inkliuzyvnoho osvitnoho prostoru [Theory and practice of social and pedagogical work with young people having special needs in the conditions of inclusive educational space]. Candidate's thesis. Starobilsk [in Ukrainian].

Shevtsiv, Z.M. (2016). Teoretychni osnovy inkliuzyvnoi pedahohiky. Onovlennia zmistu, form ta metodiv navchannia i vykhovannia v zakladakh osvity [Theoretical Foundations of Inclusive Pedagogy. Updating content, forms and methods of education in educational institutions]. Naukovi zapyski Rivnenskoho derzhavnoho humanitarnoho universytetu - Scientific Notes of Rivne State University of the Humanities, 13, 152-155. Rivne : RDHU [in Ukrainian].

Ali, B.A. (2003). The relevance of counselling in the provision of quality education for the exceptional children in Nigeria. Gobarau Journal of Education, 4 (2), 111-118.

Borg-Laufs, M. (2013). Basic Psychological Needs in Childhood and Adolescence. Journal of Education and Research, 3 (1), 41-51.

Fareo, D.O. (2015). Counselling Intervention and Support Programmes for Families of Children with Special Educational Needs. Journal of Education and Practice, 6 (10), 103-109.

Garbarino, J. (2017). Children and Families in the Social Environment : Modern Application of Social Work. New York : Routledge. 390 p.

Grawe, K. (2006). Neuropsychotherapy : How the Neurosciences Inform Effective Psychotherapy. London : Erlbaum. 502 p.

Lindsay, G. (2003). Inclusive education: a critical perspective. British Journal of Educational Psychology, 30 (1), 3-12.

Mitchell, D. (2013). Proposed values, knowledge and skill sets for educators working in inclusive settings with learners with diverse educational needs. Baltic Journal of Special Education, 2 (29), 145-157.

Ozoji, E.D. (2005). Selected issues in special education. Jos : Deka publications.

Ritzema, A., \& Sladeczek, I. (2011). Stress in Parents of Children with Developmental Disabilities over Time. Journal on Developmental Disabilities, $17,18-31$.

Wilson, J. (2002). Defining «special needs». European Journal of Special Needs Education, 17, 61-66. 


\section{АНОТАЦІЯ}

Соціальний розвиток держави пов'язаний із вирішенням низки гострих соціальних проблем, серед яких украй важливим є соціалізація дітей $з$ особливими потребами. Особливість потреб дитини зумовлена соціальною, фізичною й емоційною вразливістю та, як наслідок, необхідністю спеціальної уваги та послуг для уможливлення розвитку їх потенціалу. Незважаючи на велику кількість праць, присвячених дослідженню різних аспектів життєдіяльності дітей з особливими потребами, необхідно констатувати, що в сучасних наукових розвідках не представлено усталеної класифікації особливих потреб дітей, не розкрито їх сутності.

у статті запропоновано класифікацію особливих потреб у контексті системного підходу шляхом вивчення взаємодії дитини (як складової системи) з іншими системами різних рівнів і представлено їх коротку характеристику.

З’ясовано, що на рівні взаємодії “дитина - сім'я» (мікросистема) можливо виокремити такі потреби дитини, як: потреба в присутності іншого; потреба у прийнятті батьками та сиблінгами; потреба в постійній емочійній підтримці. До потреб рівня взаємодії «дитина найближче оточення» (мезосистема) належать: потреба в прийнятmі; потреба в самоствердженні; потреба в кваліфікованій медичній допомозі; потреба в психологічному супроводі. Групу потреб, актуалізованих взаємодією "дитина - позасімейні соціальні інституції» (езкосистема), складають: потреба в охороні здоров'я; потреба в соціальному захисті; потреба в отриманні освіти; матеріально-побутові потреби. До потреб рівня взаємодії «дитина-соиіум» (макросистема) відносяться: потреба в толерантному ставленні суспільства; потреба в економічній і політичній підтримці.

Установлено, що окреслені особливі потреби дітей детерміновані браком особистих ресурсів для оптимального фізичного та соціальнопсихологічного розвитку. Запропонована класифікація допоможе визначити засоби соціальної підтримки означеної соціальної категорії на різних рівнях взаємодії з соціальним середовищем.

Ключові слова: потреба, особливі потреби, діти з особливими потребами, системний підхід, мікросистема, мезосистема, екосистема, макросистема.

Кучманич Ирина, Опанасенко Людмила. Классификация особенных потребностей ребенка в контексте системного подхода 


\section{АННОТАЦИЯ}

Социальное развитие государства связано с решением ряда острых социальных проблем, среди которых крайне важная - социализация детей с особенными потребностями. Особенность потребностей ребенка предопределена социальной, физической, эмоциональной уязвимостью и, как следствие, необходимостью специального внимания и услуг для возможности осуществления развития его потенциала. Несмотря на большое количество трудов, посвященных исследованию разных аспектов жизнедеятельности детей с особенными потребностями, необходимо констатировать, что в современных научных исследованиях не представлена устоявшаяся классификация особенных потребностей детей, не раскрыта их суть.

В статье предложена классификация особенных потребностей в контексте системного подхода путем изучения взаимодействия ребенка (как составляющей системы) с другими системами разных уровней и представлена их краткая характеристика. Выяснено, что на уровне взаимодействия "ребенок - семья» (микросистема) можно выделить такие потребности ребенка: потребность в присутствии другого; потребность в принятии родителями и сиблингами; потребность в постоянной эмоциональной поддержке. К потребностям уровня взаимодействия "ребенок - ближайшее окружение» (мезосистема) принадлежат: потребность в принятии; потребность в самоутверждении; потребность в квалифицированной медицинской помощи; потребность в психологическом сопровождении. Группу потребностей, которые актуализированы взаимодействием «ребенок-внесемейные социальные институции» (экзосистема), составляют: потребность в здравоохранении; потребность в социальной защите; потребность в получении образования; материально-бытовые потребности. К потребностям уровня взаимодействия "ребенок-социум» (макросистема) относятся: потребность в толерантном отношении общества; потребность в экономической и политической поддержке.

Установлено, что определенные особенные потребности детей детерминированы нехваткой личных ресурсов для оптимального физического и сочиально-психологического развития. Предложенная классификация поможет определить средства сочиальной поддержки данной социальной категории на разных уровнях взаимодействия с социальной средой.

Ключевые слова: потребность, особенные потребности, дети с особенными потребностями, системный подход, микросистема, мезосистема, экзосистема, макросистема. 